\title{
Study on Aesthetic Characteristics of Sulam Usus Motif on Party Kebaya Dress (Postmodernism Era Perspective)
}

\author{
Aminah Fitria Marinda ${ }^{1^{*}}$ Martono $^{2 * *}$, Babat Nufus Tarenaksa $\mathrm{S}^{3^{* * *}}$ \\ Yogyakarta State University, Yogyakarta, Indonesia \\ *Corresponding author, Email: aminah.afm@gmail.com \\ **Corresponding author, Email: martonouny@gmail.com \\ ***Corresponding author, Email: babatnufus@gmail.com
}

\begin{abstract}
Local wisdom must not be affected by globalization and challenges in the postmodern era. The Sulam Usus craft is a form of local wisdom from Lampung that is continuously developing. This study aims to present an in-depth examination of (1) the Sulam Usus kebaya (traditional Indonesian attire) motif at Rahayu Gallery, and (2) the function of Sulam Usus kebaya at Rahayu Gallery in the postmodern era. This study was conducted on the Sulam Usus kebaya in Rahayu Gallery, Lampung. This was descriptive qualitative research. The main instrument in this study was the researcher, assisted with observation guides, interviews, and documentation. The study's supporting tools include $\mathrm{mp} 3$, digital camera, and stationeries. The data collection technique involves documentation, interviews, and observations. Data validity was obtained through detailed observation and resource triangulation. Data were then analyzed through data reduction, presentation, and conclusion. The findings reveal that: (1) the Sulam Usus kebaya in Rahayu Gallery consists of various kinds of motifs that are continuously developing from the time it was established up to now; (2) the function of Sulam Usus kebaya has shifted from its initial use as a traditional ceremony getup to a party dress. Keywords: Sulam Usus, Kebaya Motif, Postmodernism
\end{abstract}

\section{INTRODUCTION}

Craft is something valued as alternative creativity, an item produced through the skills of the hands. Generally, many handicrafts are associated with elements of art that came to be called craft art. It can be defined as the implementation of a work of art that has been mass-produced. The mass production is carried out by the craftsmen [1], and one of them is the craft artists in Rahayu Gallery.

Rahayu Gallery Lampung is a gallery that not only has a variety of creative Tapis and weaving in Lampung Province, Indonesia, but also a variety of Sulam Usus, an art inherited from the ancestors of the Lampung Pepadun tribe. The art continues to experience development as supported by its community who plays an important role in maintaining and shaping craftsmanship one of which is Sulam Usus.

So-called Sulam Usus, such art involves a technique of combining strands of cloth to resemble embroidery of usus (intestine) or tube-shaped band hand-stitched according to the desired design by means of embroidery using various threads. The technique was originally used to make the shoulder coverings of Lampung women's traditional clothing. However, along with the needs of fashion trends, Sulam Usus techniques are used not only to make traditional Lampung kebaya but have innovated, and are usually paired with Tapis cloth.
In the manufacturing process, Sulam Usus kebaya takes a long time to produce. This is because the process is complicated, so it is simply normal that the kebaya is quite expensive and has become one part of the cultural heritage in Lampung. Cultural heritage is the legacy of the ancestors containing the values of local wisdom used to live in society [2], so that cultural heritage can be found in the repertoire of local culture comprising regional languages, voice arts, traditional food, and customary ceremonies, including Sulam Usus kebaya which has existed since the past [3].

Aesthetics is everything and the study of matters relating to art activities. It is a study related to the creation, appreciation, and criticism of works of art in the context of the relationship between art and human activities and the role of art in changing the world. In addition to such matters, aesthetics is also formulated to question the nature of natural beauty and works of art or art objects or artifacts called art. Every element of fine art has aesthetic elements, namely principles to change or plan in the process of creating aesthetic values by applying elements of art [4].

Considering Sulam Usus's high aesthetic value and the growing public interest on it, such an embroidery business has developed quite rapidly in the last time with relatively higher consumer demand, the marketed products are diverse, not only to respond to the needs of clothing but to develop interior equipment marketed overseas, and, not only helping the economy of Lampung people but also assisting efforts to preserve Lampung's handicrafts. 
"Great nations are those that are able to uphold and preserve their culture," and a big challenge that occurs in the current era of globalization is to maintain the rapid progress of cultural values embodied in local wisdom of each region as it has now been reduced by foreign cultures that attack all aspects of the community life. One for this to happen might be the outburst of popular and mass media, the rapid expansion of information technology, and the overall system of globalization, therefore optimism appears through the postmodernism era [5].

Postmodernism in philosophy is defined as all critical forms of modern paradigms. The picture of the world of modernism and the social order it produces has given birth to various negative consequences that have finally triggered various postmodern movements that aim to revise the modern paradigm [6].

Besides, postmodernism art gives the understanding that art produced is art enclosing elements of the past, but also follows the development and needs of the present or future. Craftsmen and entrepreneurs who have pioneered it since the beginning of the Sulam Usus craft for the continuity of their business did not break away from traditional elements such as motifs and techniques but rather innovate it by adjusting designs to satisfy developing trends.

\section{RESEARCH METHOD}

This is a qualitative study that produces descriptive data. Such a study intends to understand phenomena about what is experienced by research subjects such as behavior, perception, motivation, actions and others holistically and by means of descriptions in the form of words and languages in a special natural context and by utilizing various scientific methods p.6 [7]. The research was carried out in the area of Jalan Soekarno Hatta No. 03, Tanjung Senang, Bandar Lampung, precisely at Rahayu Gallery Company. Sulam Usus kebaya handicraft was chosen as a subject because the craft is very attention-grabbing and unique and has become one of the characteristics of traditional and highly valued Lampung handicrafts.

With regard to data collection techniques, Sugiyono suggests four types, namely observation, interviews, documentation, and triangulation pp.63 [8]. In this study, the techniques used were observation, interviews, and documentation. Data were then analyzed by means of data reduction and presentation. Data Reduction was done by identifying units of data. As suggested, at first, data were identified as a unit, which was the smallest part found having meaning when it was associated with the focus and research problem p.288 [8]. After reduced, the data were presented and clarified, and then conclusion drawing or verification was carried out to write the report.

\section{FindingS AND DiscuSSION}

\section{A. Lampung's Sulam Usus kebaya motifs as a visual manifestation of traditional craft art with distinguishing characteristics}

The manufacturing process itself involves handmade or hand-craft skills to work on a piece of the base cloth which is cut diagonally and sewn to resemble the usus after which it is affixed and stuck on a patterned paper and drawn on a motif. Then, it is embroidered on a pattern then connected and its stitches are released so that the final product becomes a wonderful piece of kebaya. Some examples of kebaya embroidery patterns are presented in Fig. 1 to Fig. 4 below.

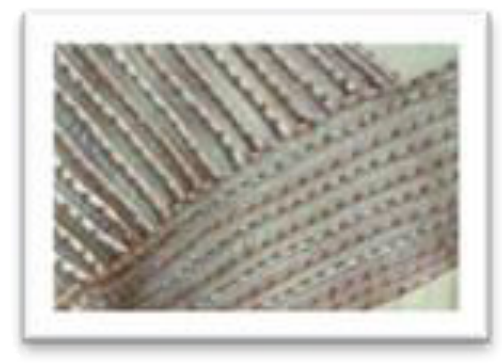

Fig. 1. Transecting Technique

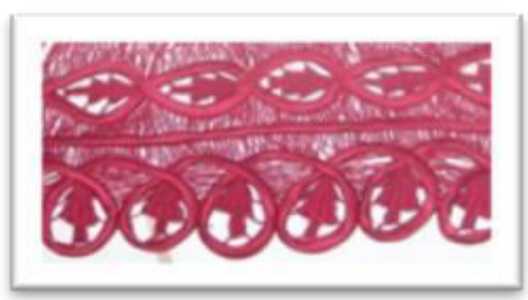

Fig. 2. Cross Technique

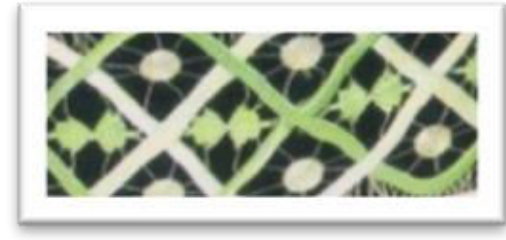

Fig. 3. Butterfly Technique

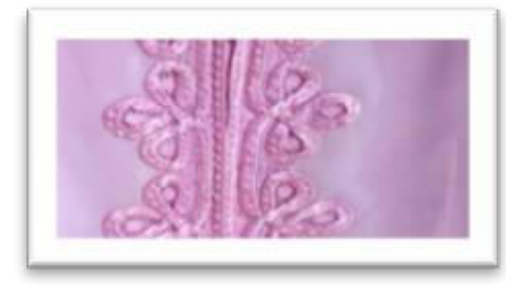

Fig. 4. Sphere Technique

1. In its development, Sulam Usus motifs in the gallery cover not only just straight lines but also various beautiful and unique creations. Today, hand-crafting Sulam Usus craft has become the livelihood of people living in Lampung. 
2. The shape and size of the Sulam Usus kebaya displayed were customized in various creative kinds and the products have a beautiful and attractive look with varied motifs mostly in geometric and floral patterns crafted with various techniques.

3. Sulam Usus Kebaya in the gallery has a variety of motifs consisting of a combination of designs that reflect the traditional Lampung Kebaya.

4. The embellishments applied to the products displayed in Rahayu Gallery are only ordinary embroidery with cross techniques and have developed into geometric and floral patterns featuring flowers, vines, and leaves. The variety is taken from a number of forms of Lampung ornamentation originating from nature and distillation in such a way that becomes widely held motifs. The decoration in the Rahayu gallery is the result of the owner's self-creation as well as inspirations from various gallery visits as well as observations and literary studies from various media. These crafts likely support the formation of Sulam Usus innovation in the era of postmodernism and do not eliminate the long-standing element while maintaining its traditional features. Besides, decorative ornaments originating from faunas are only made based on consumer orders

5. The kebaya applies the principle of fine art, which is harmony wherein one and the other motifs are skillfully arranged to give a combination and harmony. Another element of fine art is also applied, that is Rhythm (repetition) where the motifs used are made repeatedly but still one unit and in balance, as clearly visible from its use of monochromatic colors. The kebaya also applies the principle of space and time in which its size suits the female body, likewise, parts such as hands and the front and back bodies since each joint is handstitched with 555 nylon.

\section{B. The Functions of Lampung's Sulam Usus Kebaya in the Postmodern Era}

Sulam Usus kebaya now increasingly evolving and innovating, of course, is inseparable from the function of the kebaya itself. Originally made, the kebaya was designed as a costume for the traditional Lampung bride with bebe or cover on the shoulder that makes it typical at Lampung traditional ceremonies. In the postmodernism era, however, this attire can be used in non-formal or daily events like hanging out with friends.

Sulam Usus kebaya has been designed and modified according to its development, such as for non-formal events, as crafted without sequins or beads and also non-full embroidery so it can be mix-matched with the other kinds of cloth, like cotton. Besides being able to be used in nonformal occasions, this kebaya automatically is used mainly in formal events, namely Lampung traditional wedding parties, graduation ceremonies, formal birthday parties, and meetings with important people. The kebaya can also be matched with a Lampung Tapis cloth that gives the wearers elegant impression.

The work of kebaya with Sulam Usus techniques in Rahayu Gallery made is an innovation effort of kebaya design in general by elevating traditional craft techniques from Lampung. The embroidery techniques are combined with other kinds of embroidery and sequins to produce an nicelooking kebaya. The final designs resemble innovative development from existing Sulam Usus kebaya designs. Finally, the designs create some kebaya dresses that bear a resemblance to an evening gown and accentuates sensuality.

- This kebaya can also be worn on official occasions such as formal celebrations. Through Sulam Usus crafts, public knowledge about hand-crafted textile from Lampung increased. In addition, this kebaya can increase artists' inventiveness in making innovations in textile works.

- In the beginning, Sulam Usus embroidery was part of a set of traditional wedding attire from the Lampung area. It initially functions as a covering of the chest (bebe) stitched on the Tapis fabric.

- $\quad$ Furthermore, Sulam Usus can be skillfully fashioned as common clothes, kebaya, or dresses and with other monochromatic fabric to make outfits harmonious.

- The strengths of Sulam Usus products lay on their classic shape and model, soft exterior, and warm look, without making its wearers feel stiflingly hot.

\section{Conclusions}

Based on the results of research and discussion of the motives and functions of the traditional Sulam Usus kebaya, in Rahayu Gallery in the postmodernism era, some conclusions are formulated as follows.

Sulam Usus has its background from embroidery made of tube-shaped satin band either straightly or curvaceously stitched based on unique motifs. The satin bands are stitched with gold thread and some even complemented with small pieces of ancient crystals and coins. In the past, Sulam Usus was part of the traditional attire of the bride in the Lampung region, which functioned as a breast covering (bebe) on a Tapis cloth. Besides, Sulam Usus cloth has been created into clothing, kebaya, or dress combined with other matching textiles. Sulam Usus also has a variety of designs and accessories. Besides having a distinctive classic motif of Lampung, Sulam Usus fabric is sought after by tourists as one of the typical souvenirs from Lampung. As for its manufacturing process, Sulam Usus crafting is complicated and requires great patience in its process. As an example, it takes a week of knitting to make a kebaya manually without any machine.

In addition to its special characteristics, motifs developed in Sulam Usus are natural. Its hand embroidery results in various motifs, not only straight lines but also a lot of beautiful and unique motives and are mostly geometric and floral. Having various kinds of motifs entailing combinations or variations that reflect the traditional Lampung Kebaya, geometric ornamentation and flora decoration (flowers, vines, and leaves) have possibly been the most favorite in its kind. The variety is taken from several forms of Lampung ornamental variations which are the results of the creation of the local people and also the contribution of consumers and craftsmen. However, the decorative embroidery motifs of 
kebaya in Rahayu Gallery had not been formally registered so that other parties may possibly copy them for their own benefit. The motifs are presented in Fig. 5 below.

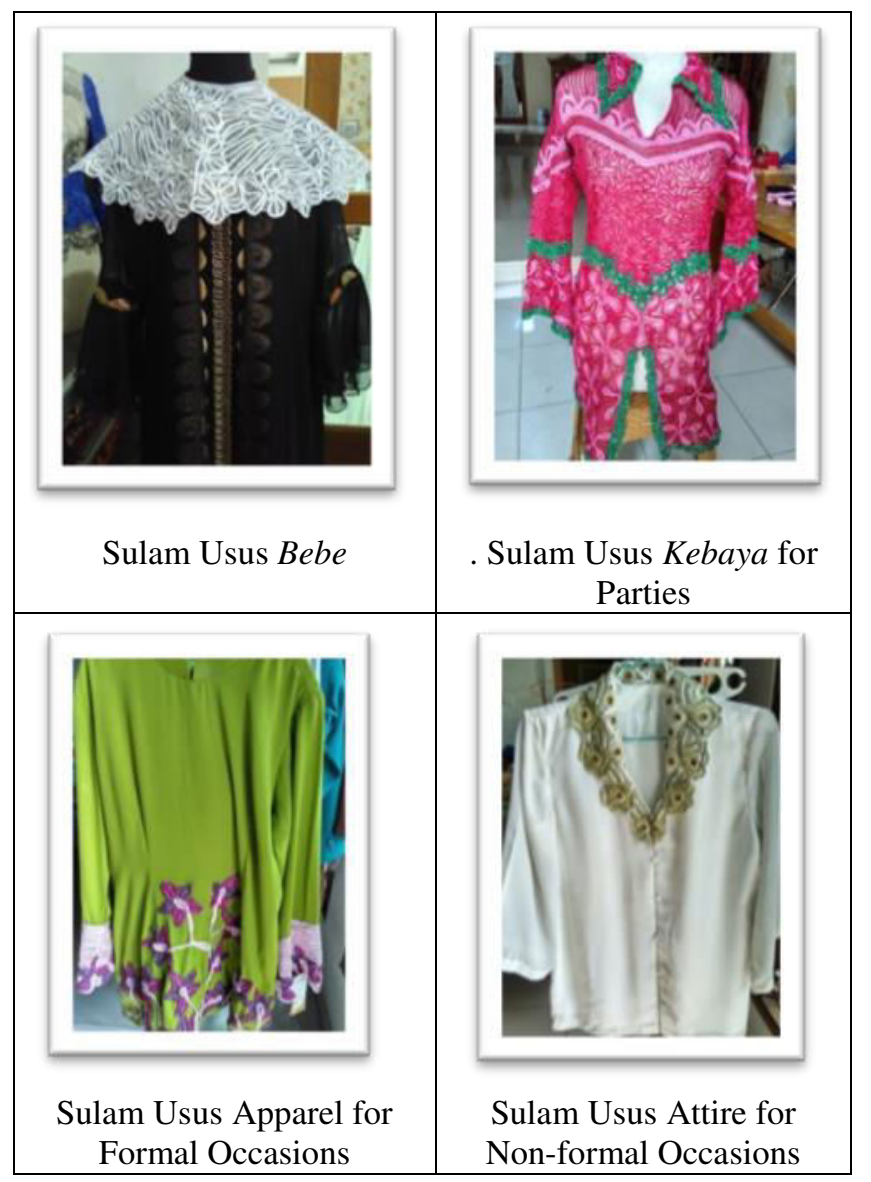

Fig. 5. Sulam Usus Kebaya Creations

Considering the conclusions on Lampung's Sulam Usus motifs and functions on its users, this study implies that Sulam Usus craft art as functioning in the postmodernism era has shown its existence as local wisdom for shaping the characters of young generations or students. As expected in the educational context, these members of the community, students, are expected to have better social sensitivity, uphold the values of local wisdom, and develop their critical thinking on the inequality existing in the community based on the functions of art itself as a product of human critical reflection.

\section{REFERENCES}

[1] Raharjo, Timbul. "Seni Kriya dan Kerajinan [Craft Arts]." Yogyakarta: Program Pasca Sarjana Institut Seni Indonesia (2011).

[2] Sutiyono, "Paradigma Pendidikan Seni Indonesia". Yogyakarta: UNY Press (2012).

[3] Dharmamulya, Sukirman. "Pelestarian Permainan Anak-anak Tradisional Perlu di Upayakan,
Yogyakarta: Direktorat Jarahnitra, Lembaga Javanologi (1996).

[4] Agus, Sachari. "Estetika Makna Simbol dan Daya [Aesthetics: Meanings, Symbols and Power]." (2002).

[5] Suherman. "Pendidikan Seni dan Penyadaran", Yogyakarta: Thafa Media (2017).

[6] Sugiharto, I. Bambang. Postmodernisme: Tantangan bagi Filsafat. Kanisius, 1996.

[7] Moleong, Lexy J. "Metode Penelitian Kualitatif [Qualitative Research Methods], cetakan keempat belas." Bandung: PT Remaja Rosdakarya (anggota IKAPI) (2001).

[8] Sugiyono, P. D. "Metode penelitian kuantitatif dan kualitatif dan R\&D [Quantitative and qualitative and $\mathrm{R} \& \mathrm{D}$ research methods]." Bandung, Indonesia: Alfabeta (2013). 